\title{
Causes of Delay in the Resolution of Commercial Disputes Via Litigation: Arbitration as a Way out withn Ohada Laws
}

\author{
Buma Roland Sigala \\ PhD in Law, University of Dschang, Dschang, Cameroon, Central Africa
}

\begin{abstract}
How to cite this paper: Buma Roland Sigala "Causes of Delay in the Resolution of Commercial Disputes Via Litigation: Arbitration as a Way out withn Ohada Laws" Published in International Journal of Trend in Scientific Research and Development (ijtsrd), ISSN: 24566470, Volume-3 | Issue-4, June 2019, pp.927-934, URL: https://www.ijtsrd.c om/papers/ijtsrd23 940.pdf

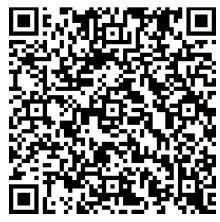
IITSRD23940
\end{abstract}

Copyright (C) 2019 by author(s) and International Journal of Trend in Scientific Research and Development Journal. This is an Open Access article distributed under the terms of the Creative Commons

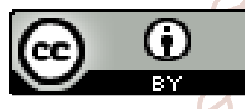
Attribution License (CC BY 4.0) (http://creativecommons.org/licenses/ by/4.0)

Justice has been done or not. Delay can lead to injustice. This is so because delay can be considered to be denial of justice. It can act as an obstacle to the plaintiff and a protection to the defendant. ${ }^{4}$ No one notes the fact more surely than the

${ }^{1}$ On the $17^{\text {th }}$ of October 1993 , the OHADA treaty was signed in Port-Louis by 14 heads of States from French speaking Africa (Benin, Burkina-Faso, Cameroon, Central Africa Republic, Comoros, Congo- Brazzaville, Côte d'Ivoire, Gabon, Equatorial Guinea, Mali, Niger, Senegal, Tchad and Togo). Subsequently two other countries joined the organization (Guinea Conakry and Guinea-Bissau). Today, the organization has 17 members. The most recent member to joint the organization is the Democratic Republic of Congo. The objectives of OHADA are as follows : the determination to accomplish new progress on the road to African unity and to establish a feeling to trust in favor of the economies of the contracting states in a view to create a new center of development in Africa; to reaffirm their commitment in favor of the establishment of an African economic ; the fact that their membership in the franc zone is an economic and monetary stability factor and constitutes a major asset and that this integration must be carried on a larger African frame work; the fact that the realization of those objectives demands an application in the contracting states of a business law which is simple, modern and adaptable; it is essential that the law to be applied with diligence in such conditions so defendant. Hence delay is his first line of defence. It is more valuable to him or her. He or she recognizes that lapse of time softens the zeal of the trial, impairs its forces and strengthens a fictitious defence. ${ }^{\mathbf{5}}$

\footnotetext{
as to guarantee legal stability of economic activities and to favor the expansion of the latter and to encourage investment; the desire to promote arbitration as an instrument to settle contractual disputes; and the determination to participate in common new efforts to improve the training of judges and representatives of the law.

${ }^{2}$ See, the Magnacarta of 1215 , in which it is stated that, «to no one will we sell, to no one will we refuse or delay, right or justice».

${ }^{3}$ SOURDIN (T.) and NAOMI (B.), «Justice Delay is Justice Denied», Australian Center for Justice Innovation, 2009, p.46.

${ }^{4}$ BARNES (A-C.), «Causes of Delay in Criminal Cases», Journal of Criminal Law and Criminology, vol.7, May 1916-March 1917, p.83.

5 Ibid
} 
Delay is used to refer to a situation where time has elapsed that is avoidable. ${ }^{6}$ Delay can also be understood to mean a situation where something happened later than it should, slower than desired or even postponement. Thus, once there is a postponement (a practice which is common in the courts or litigation), it means there is delay. Also, when judgment is delivered later than desired by the parties, it means there is delay. This practice is also common in the Courts where sometimes the court will render judgment later than it was desired by a party or even all the parties in the dispute.

Delay has a negative impact in that it results in dissatisfaction to litigants. For example, where there are unnecessary postponements, each postponement wastes time and increases cost to the litigants. In litigation or disputes resolution via the courts, sometimes even something that is so straight forward goes through prolong processes.

Delay is an important element in determining the level of satisfaction of litigants. Thus, where there is delay, litigants will be unsatisfied even though judgment has finally been delivered.

Because of the delay inherent in litigation, it is preferable to use arbitration to resolve commercial disputes. In business, time is money. Arbitration is preferred than litigation as a means of resolving commercial disputes because of the expediency of arbitration. Arbitration proceedings can be rapid than proceedings before the normal courts. ${ }^{7}$

The OHADA legislator encourages arbitration as a mode of contractual dispute settlement. ${ }^{8}$ But it failed to define this concept. ${ }^{9}$ However, arbitration can be defined as a private process of dispute resolution between parties to an arbitration agreement. ${ }^{10}$ Arbitration may be broadly described as a private process which commences with the agreement of the parties to an existing or potential dispute to submit that dispute for decision by a tribunal of one or more arbitrators.

Arbitration may be either institutional, that is conducted under the auspices of an arbitration center which administers the arbitration according to its rules, or ad hoc that is conducted without the assistance of an arbitration center and in accordance with any rules that the parties or the arbitral tribunal may choose to apply, subject to any

${ }^{6}$ Chief Justice WAYNE MARTIN, «Because delay is a kind of Denial» (Speech delivered at the Timeliness in the Justice System: Ideas and Innovation Forum, Monash University Law Chambers, 16to17May2014), source:http://www.civilJustice.info/cgi/viewcontent.cgi/v iewcontent.cgi?article $=1015 \&$ context=timeliness. $\quad$ Last visited on the $30^{\text {th }}$ of September 2015.

${ }^{7}$ TUMNDE née NJIKAM (M.), « Arbitration : The Anglophone Cameroon Experience», Revue Camerounaise de l'arbitrage, Numero special (2), Fevrier 2010, p. 181.

${ }^{8}$ See Article 1 of the OHADA Treaty.

${ }^{9}$ The OHADA treaty, Uniform Act on Arbitration, CCJA Rules of Procedure and CCJA Rules of Arbitration did not provide a definition for arbitration.

10 POUGUE (P.G.), TCHAKOUA (J-M.), FENEON (A.), Droit de l'arbitrage dans l'espace OHADA, Col. Droit Uniform, PUA, 2000, p.8. mandatory rules laid down by the applicable law. ${ }^{11}$ OHADA recognizes both institutional and ad hoc arbitration. In this light, OHADA has created different sets of legislations applicable to arbitration. There is the OHADA treaty itself, which provides for institutional arbitration under the auspices of the Common Court of Justice and Arbitration (CCJA), in accordance with the CCJA's own Rules of Arbitration. There is the Uniform Act on arbitration, which lays down basic rules that are applicable to any arbitration (ad hoc or institutional) where the seat of the arbitral tribunal is in one of the member states.

Arbitration can be domestic or international. Domestic arbitration involves a state's own domiciliary and nationals. ${ }^{12}$ International arbitration is an arbitration in which all the aspects in the arbitration are not limited to a single state. For example, an arbitration in which the parties in the dispute, the arbitrators, the place of the arbitration, the procedure of the arbitration etc. does not concern a single state. ${ }^{13}$ In some countries, there is a difference between domestic and international arbitration. ${ }^{14}$ Under OHADA, Article 1 of the Uniform Act on Arbitration (UAA) states that: " the Uniform Act shall apply to any arbitration where the seat of the arbitral tribunal is located in one of the member states». The intention of Article 1 of the OHADA UAA is that the Uniform Act should apply to all arbitrations where the seat of the tribunal is located in a member state. This means that the Uniform Act makes no distinction between domestic and international arbitration.

As to what is a "commercial" dispute, Article 1(1) of the United Nations Commission for International Trade Law (UNCITRAL) Model Law 1985 provides that it should «be given a wide interpretation so as to cover matters arising from all relationships of commercial nature, whether contractual or not».15 The OHADA legislator has facilitated the task of identifying commercial disputes by making a list of commercial acts in the OHADA Uniform Act on General Commercial Law. This Uniform Act gave a list of two categories of commercial acts namely commercial acts by nature and commercial acts by form. ${ }^{16}$

${ }^{11}$ MARTOR (B.) et al, Business law in Africa: OHADA and the Harmonisation Process, 2 ${ }^{\text {nd }}$ Ed., Eversheds, 2002 p. 255.

${ }^{12}$ HULEAT(M- J.) and GOULD(N.), International Commercial Arbitration: A Handbook, LLP Limited, London, New York, Hong Kong, 1996, p. 3

13 See,LALVIE (V-P.), « Problèmes relatif à l'arbitrage international commercial», Recueil des Cours de l'Académie de Droit International de la Haye Martinus Nijhoft, 1967, Tome 120, p.569 to 714, No. 580.

14 For example in the People's Republic of China. In such countries, the rules applicable to domestic arbitration is not similar in all aspects to rules applicable to international arbitration.

15 Note that according to the provisions of the New York Convention on the Recognition and Enforcement of Foreign Arbitral Awards of 1958, the commercial nature of a dispute is of particular importance when an attempt is made to enforce an arbitration agreement or the recognition as enforcement of an award is sought.

16 See Arts 3 and 4 of the OHADA Uniform Act on General Commercial Law. 
A dispute may be defined as a specific disagreement concerning a matter of fact, law or policy in which a claim or assertion of one party is met with refusal, counter-claim or denial by another. ${ }^{17}$

It has been found out that when commercial disputes are settled through the medium of litigation or the normal courts, it occasions to waste of time whose effects are not of interest to profit maximization.Thus, arbitration is preferred than litigation in the resolution of commercial disputes because of the fast nature of arbitration.

From the forgoing, an important question which can be raised is that, what are the techniques used in arbitration to fight against the causes of delay in litigation? This article aims at identifying the causes of delay in litigation (I) and how these causes of delay have been avoided or combated by arbitration in order to ensure speed in arbitration (II).

\section{The causes of delay in litigation}

A number of factors account for delay in litigation. These causes include absence of timeline for the finalisation of litigation (A), obligatory recognition of the right to make a counterclaim (B) and the possibility to make appeal or recognition of the right to make an appeal (C).

A. Absence of a timeline for a litigation to be finalised Timeliness is a complex and subjective concept, which means that, it may be defined differently by disputants, legal practitioner and other professionals, academicians, courts staff, administrators, judges and others, ${ }^{18}$ Timeliness means no time limit.

Within the OHADA laws, the state judges are under no obligation to finalise a civil case with a given timeline. This can permit unnecessary prolongation of the hearing. Unnecessary prolongation of the hearing can be caused by the following factors:

Firstly, where for example the defendant has no defence, he or she is naturally interested in prolonging the trial with a view to put off the evil day as long as possible. ${ }^{19}$ In such situations, advocates will use their ingenuity to look for technical elements which will assist the defendant to prolong the trial.

Secondly, an advocate can use the advantage of absence of timeline for the finalisation of a dispute via litigation or state court to see the finalisation of the dispute prolonged for his or her financial interest. Some advocates instead of setting fee on lump - sum basis prefer to settle it on daily basis. That is the fee of an advocate is directly proportional to the number of hearing. An unscrupulous lawyer tries to stretch a case to as many hearing as possible by seeking adjournment

17 MERRILIS (J.B), International Dispute Settlement, 3rd Ed., Cambridge University Press, 1998, p.1.

18 SOURDIN (T.), «The Timeliness Project: Background Report», Australian Centre for Justice Innovation, 2013.

${ }^{19}$ SAZZAD HASSAIN (M.) and IMAM HASSAIN (M.), «Causes of Delays in the Administration of Civil Justice: A look for Way Out in Bangladesh Perspective», in ASA University Review, Vol. 6 No. 2, July -December, 2012, P. 103. on one pretext or the other ${ }^{20}$ which causes accumulation of areas.

Thirdly, it is also worth mentioning that some advocates take up a lot of work, which is not possible for them to attend to all the cases within the required time expected by the parties. This results in seeking adjournment of cases thereby, facilitating in accumulation of areas.

Fourthly, absence of timeline for the finalisation of litigation has given the judges a liberal attitude in respect of adjournment. A judge can adjourn a case even if the adjournments were not necessary for their own interest without being sanctioned. Such adjournments can even take months.

Beside the absence of a timeline for the courts to finalise a dispute, another factor which acts as a cause of delay in litigation is the recognition of the right to a counterclaim. When this right is exercised, it will add more work load to the tribunal and consequently prolonging the time for the dispute to be finalised.

\section{B. The obligation of the court to recognise the} defendants' rights to make a counterclaim

The concept of counterclaim is a concept of private law, and in particular, of civil procedure law. A counter claim is a claim by a defendant opposing the claim of the plaintiff. This will consequently add more work load to the tribunal and hence time consuming for the dispute to be finalised.

A counterclaim contains assertions that the defendant could have started a lawsuit if the plaintiff had not already begun the action. A counterclaim is in substance a cross action independent of the plaintiff's claim.

It is governed by the same rules that regulate the claims made by a plaintiff except that it is part of the answer that the defendant produces in response to the plaintiff's complaint.

Where there are more than one party on a side, a counterclaim may be made by any defendant against any plaintiff or plaintiffs.

The right of the respondent to bring a counterclaim or "cross action" is admitted by virtually all municipal civil procedure legislation. It is admitted in USA, England and other countries.

Under English Law, counterclaim is governed by the S.C.C.P.R (Supreme Court Civil Procedure Rules) and the Judicature Act of 1925.21 Or. 37.7 SCCPR provides that: " every statement of claim shall state specifically the relief which the plaintiff claims either simply or in the alternative and may also ask for general relief and the same rule shall apply to any counterclaim made or relief claimed by the defendant in his defence ».

For a counter claim to be admissible, some conditions must be respected which are:

${ }^{20}$ For example an unscrupulous lawyer can say he or she is just getting the case and needs time to study it.

${ }^{21}$ See section 39 of the Judicature Act 1925. 
Firstly, it must always be pleaded by the defendant in his statement of defence. It cannot be pleaded outside his statement of defence. ${ }^{22}$ If the defendant failed to do so, all he needs to do is to file a motion on notice for an order to amend his statement of defence hereby including his counterclaim. But in Cameroon Bank Vs Paul Senju suit Number High Court South West Province (HCSWP) /12/77, Monekoso J. took a different view. In this case, the plaintiff applied for a writ of summons under Or. 3r.9 Supreme Court Civil Procedure Rule. The writ was filed at the registry of the High Court of Buea on the $25^{\text {th }}$ march 1977 . On October $12^{\text {th }}$ 1977 the defendant filed a statement of defence without pleading his counterclaim. On matters outside and without leave of court he filed his counterclaim on the hearing of the matter on March 21 $1^{\text {st }} 1979$. The plaintiff applied by motion on notice for an order to strike out the counterclaim, or alternatively for an extension of time to file a defence to the counterclaim. The learned trial Judge ruled that the counterclaim was probably brought at before him. He however granted leave to the plaintiff to file a defence to the counterclaim. Professor P.Y Ntamark respectfully submitted that, the learned trail Judge erred in doing so. The defendant should have pleaded the counterclaim in his defence and having failed to do so he ought to have sought for an order of the court to amend his claim. ${ }^{23}$

Secondly, the plaintiff is required as a defendant to be well served with a statement of claim to file a defence to the defendants counterclaim. ${ }^{24}$

Thirdly, it must contain facts sufficient to support the granting of the relief to the defendant if the facts are proven to be true. These facts may refer to the same event that gave rise to the plaintiff's cause of action or they may refer to an entirely different claim that the defendant has against the plaintiff.

Once the conditions to make a counter claim have been respected, the court must allow the counterclaim. A counterclaim will certainly add more work load to the tribunal and hence prolong the time for the dispute to be finally settled.

In addition to the right to make a counterclaim and absence of a stated timeline for a dispute resolved by way of litigation to be finalized, another element which makes litigation to be time consuming is the obligation of the court to recognize the right of a litigant to make an appeal.

\section{Obligation of the court to recognize the right of a litigant to make an appeal}

The recognition of the right to make an appeal increases the length of time to resolve a dispute by way of litigation. Appeal descends from the Latin word "appellare" meaning "to address, call... upon". Appeal means to call upon a higher court to review a lower court's decision. For example if a person appeal against a court decision awarding damages against him or her, he or she is asking a higher court to throw out the decision. According to the principle of double degree of justice, a litigant who is not happy with the

22 Or. 32 r.14 of the SCCPR.

23 MBETIGI (M.), Lecture Notes on Civil Procedure, FSJP, Dschang, 2015-2016, P. 51

${ }^{24}$ See the case of Dr. Aletum Tabuwe Michael Vs Nchotu William and J.M Nyamboli, Appeal No BCA/6/87(unreported). decision of a court at First Instance can make an appeal to a Second Degree Court.

Although this principle is important because it ensures that an error committed at First Instance could be corrected, sometimes a litigant can hide behind the shield of double degree of justice to make an appeal in bad faith. This is the case with a litigant who knows that the judgment rendered at First Instance was a fair judgment but he or she still decides to make an appeal in order to prolong the finalisation of the dispute.

Once a litigant respects the conditions to make an appeal, the appeal can lead to suspension of the judgment rendered at First Instance . The suspending effect of an appeal means that the contested decision has no legal effects until the appeal is resolved. In other words, the suspending effect of an appeal deprives the contested decision of all legal effects until the appeal is decided. The suspending effect of an appeal transforms the judgment rendered at First Instance to be a mere piece of paper without any binding force. This provision can be seen in Article 203(1) of the French Code of Civil and Commercial Procedure (CPCC).

Since the suspending effect of an appeal is an obstacle for the execution of a judgment rendered at First Instance, this will also act as a factor to increase the length of time for the resolution of the dispute.

The suspending effect of an appeal as a factor which increases the length of time for the finalisation of a dispute is felt even in those instances where they were many parties in the dispute, some intending to accept the judgment rendered at First Instance and some intending to make an appeal. In this case, the judgment rendered at First Instance shall not be suspended on those who never intended to make an appeal, but the judgment shall be suspended on those who made the appeal while waiting for the Appeal Court to decide on the case. This is known as «the principle of divisibility of appeals». Thus, in a dispute involving many persons, some litigants may not intend to see the dispute last for long whereas others may intend to see the dispute last for long.

In order to fight against delay in the resolution of commercial disputes it is necessary to look for mechanisms through which the above explained causes of delay can be avoided. These causes of delay have been avoided in arbitration through the use of a number of mechanisms.

\section{Safeguards for expediency in arbitration: The mechanisms through which arbitration has combated the causes of delay witnessed in litigation}

Arbitration is faster than litigation. This rapidity has been achieved by avoiding the delays inherent in litigation. The causes of delay in the final resolution of disputes through the use of litigation have been avoided in arbitration. This can be justified as follows: in arbitration, there is a timeline for a dispute to be finalized (A), there is the possibility to exclude the right to make a counterclaim in the arbitration agreement (B), some types of recourses against the award are prohibited (C) and the acceptance of a decision setting aside the judgement of a competent judge in the member state only when the application is directed to the CCJA (D). Under the New OHADA Uniform Act on Arbitration of 23rd 
November 2017 provision has expressly been made for the rapidity of arbitration. ${ }^{25}$

\section{A. In arbitration, there is a timeline for a dispute to be finalized}

Contrary to litigation where there is no timeline for a dispute to be finalized, in arbitration, there is a timeline for a dispute to be finalized by the arbitral tribunal. The time limit for determining a claim is fixed by the arbitration agreement. But where no such agreements exist, the assignment of the arbitrator may not exceed six months from the date when the last of them accepted the assignment. ${ }^{26}$ The six months deadline is guaranteed or made effective through the use of the following mechanisms:

Firstly, there is a time limit for the appointment of arbitrators. Article 8 Paragraph 1 of the OHADA U.A.A provide that: " the arbitral tribunal shall be composed of a sole arbitrator or a panel of three arbitrators». Since an arbitral tribunal can be made up of one or three arbitrators, difficulty in the appointment of arbitrators can be witnessed when the tribunal is composed of one arbitrator and when the tribunal is composed of three arbitrators.

When the arbitral tribunal is made of a single arbitrator, the parties are free to choose their arbitrator in the arbitration agreement. ${ }^{27}$ Where there is a single arbitrator, there is no problem when the parties freely agree on a particular arbitrator within the required time to settle the dispute. Problems are bound to arise when the parties are unable to agree on a particular arbitrator within the time limit given to them by the OHADA legislator to mutually agree on the arbitrator who shall settle the dispute. The time limit for the parties to mutually agree on the arbitrator is thirty (30) days. When the parties are unable to mutually agree on the arbitrator within thirty (30) days, then the appointment shall be done by the competent judge in the member state at the request of a party ${ }^{28}$ in the dispute. This applies when the arbitration is ad hoc. ${ }^{29}$ In institutional arbitration, when the parties are un able to agree on the sole arbitrator who shall hear the case, any of the parties can make an application to the arbitration center under whose auspices the arbitration is to be conducted requesting the arbitration center to appoint the sole neutral arbitrator who shall hear the case. For example in arbitration conducted under the control of the CCJA, if the parties are unable within thirty days to agree on the neutral arbitrator, any of the parties can make an application to the CCJA demanding it to appoint the arbitrator. $^{30}$ Within OHADA, this solution (allowing

25 See Article 4 of the OHADA Uniform Act on arbitration of 23 November 2017.

${ }^{26}$ See Articles 30(1) ICC Rules of Arbitration, 12(1) of the OHADA U.A.A.

27 Article 5 of the OHADA U.A.A provide that: « arbitrators shall be appointed, dismissed or replace in accordance with the agreement of the parties».

${ }^{28}$ Article 5 paragraph 2 of the OHADA UAA.

29 AMADOU DUENG, «Les difficultés de constitution du tribunal arbitral dans le cadre de l'arbitrage ad hoc», Revue Camerounaise de l'Arbitrage, Numéro Spécial (2), Février 2010, p. 89.

30M'BOSSO (M-J.),«Premiere biland de l'application des instruments OHADA relatif à l'Arbitrage: le cas de L'Arbitrage CCJA», Revue Camerounaise de l'Arbitrage, Numéro Spécial (2), Février 2010, p. 165. competence only to the arbitration center and not to the state judge to appoint arbitrators in the event of difficulty in the appointment of arbitrators) is found in the Arbitration Rules of Groupement Inter-Patronal du Cameroun (GICAM), ${ }^{31}$ Chambre de Commerce d'industrie etd'agriculture de Dakar ( CCIAD), ${ }^{32}$ Cour d'arbitrage Cote d'ivoire (CACI), ${ }^{33}$ CCJA ${ }^{34}$ etc.

When the tribunal is made of three arbitrators, if the two appointed arbitrators are unable to agree on the third arbitrator within the required deadline, then the arbitrator can seize the competent court to appoint the third arbitrator. In situations where the arbitration is institutional, if the two appointed arbitrators are unable to agree on the third arbitrator within the required deadline, then the arbitrator can seize the arbitration center under whose auspices the arbitration is conducted to appoint the third arbitrator.

Secondly, an arbitrator can be replaced if he or she is unable to finalize the dispute within the required given time limit. Article 4.4 of the CCJA Rules of Arbitration stipulates that: "the Court shall replace an arbitrator when it establishes that... the arbitrator does not perform his or her function... within the prescribed limit ». By Article 8 of the OHADA U.A.A, in the event of death or resignation of an arbitrator during the course of the arbitral proceedings a substitute shall be appointed in accordance with the agreement of the parties or in absence of any such agreement, by the competent judge in the member state. The same procedure shall apply in the event of an arbitrator failing to act due to incapacity. Although the draftsman has not stated clearly what amounts to incapacity, this should be in relation to an impediment to perform the mission of an arbitrator for example illness. ${ }^{35}$ Thus, where the parties discover that the arbitrator shall be unable to finish the dispute within the required time because of illness, they can proceed to the replacement of the arbitrator.

Thirdly, there is a time limit for the issuance of the award after the closure of the arbitral proceedings. In the CCJA Rules of Arbitration, the time limit for the issuance of the award is 90 days after the closure of the proceedings as compared to 60 days from the appointment of the last arbitrator under the Uniform Act. ${ }^{36}$

In addition to the existence of a prescribed time limit for a dispute resolved by way of arbitration to be finalized, the expediency of arbitration has also been guaranteed by

${ }^{31}$ See Article 9.

32 See Articles 11 and 12.

33 See Article 12.

34 To this effect Article 3.1 of the CCJA rules of Arbitration respectively provide that: if at the expiration of 30 days from the date of notification to appoint arbitrators, the parties are unable to agree on the arbitrator or if the two appointed arbitrators are unable to agree on the third arbitrator within the required time fixed by the parties or the court, the appointment shall be done by the court.

35TAYI TATSI (T.), Simplified procedures for debt recovery and arbitration: the practice in Anglophone Cameroon an innovations of OHADA Uniform Acts (A comparative study), master's thesis, University of Dschang, 2011, p.85.

${ }^{36}$ See Article 15.5 of the CC JA Rules of Arbitration. 
allowing the party the possibility to prohibit the right to make a counterclaim in arbitration.

\section{B. The possibility to prohibit the right to make a counterclaim}

In arbitration like in litigation, there is the recognition of the right to make a counterclaim. But contrary to litigation where there is no possibility to prohibit this right, in arbitration, there is the possibility to prohibit the right to a counterclaim in the arbitration agreement. That is the parties can expressly stipulate in the arbitration agreement that the right to make a counterclaim is prohibited.

For some authors, counterclaim is prohibited in arbitration. This is the case with Anziloti ${ }^{37}$ who ruled out the possibility of counterclaims in arbitration.

For another author, counterclaim is prohibited in arbitration only when the parties stipulate this prohibition in the arbitration agreement. For this author, counterclaim is not totally excluded in arbitration. According to this author, counterclaim is prohibited in arbitration only when the parties in the arbitration agreement made a stipulation prohibiting counterclaim. This is the case with Scelle in his report to the International Law Commission on Arbitration. His report to the International Law Commission on Arbitration shows that in arbitration, counterclaims were not precluded in principle in the absence of an express provision in the compromise. 38

There is no doubt that all arbitrations are governed by the terms of the special agreements that established them. Whether a counterclaim may be raised or not by either of the parties is a matter first, of the terms of the compromise. If the compromise expressly excludes the making of counterclaim, then the issue is settled there. But if it is silent, then it is a matter of how the dispute is defined. If this is formulated in a narrow and specific terms, then the possibility of raising counterclaims equally narrows to the point of exclusion. On the contrary, if it is defined broadly and if it can be deduced from the terms of the special agreement that the intentions of the parties is to achieve a final settlement of all outstanding issues pending between them, then counterclaim may not be excluded simply because the method of settlement is arbitration.

As said earlier, counterclaim is prohibited in arbitration only when a provision was made in the arbitration agreement to this effect. Thus if the disputants intend to minimise the time for the finalisation of the dispute, they can stipulate in the arbitration agreement that counterclaim is prohibited. It is therefore obvious that if the parties are silent on the exclusion of the right to make a counter claim and it is also deduced from the intensions of the parties that they never intended to exclude the right to make a counterclaim, then the right of a party to make a counterclaim in arbitration is well recognized.

${ }^{37}$ ANZILOTTI (D.), La Demande Reconventionelle en Procedure International, 57 J du Driot International 857, 1930.

${ }^{38}$ Report by GEORGES SCELLE (Special Rapporteur) on Arbitration Procedure, Doc. A/CN.4/18 (1950), Yearbook of the International Law Commission 1950, Vol. II, 114 at 137, paragraph 78 .
The possibility to make a counterclaim in arbitration can be seen in Article 7 of the Common Court of Justice and Arbitration Rules. This Article stipulates that: «if the defendant has introduced a counterclaim in his statement of defence the claimant may within thirty (30) days of receipt of his defence, present a supplementary note on the issue».

Arbitral tribunals have been ready to entertain issues of counterclaims if it was not prohibited in the arbitration agreement. This is the case with the International Chamber of Commerce (ICC) where the tribunal listened to the raised counterclaim before dismissing them. In case No $3779^{39} \mathrm{a}$ Swiss Seller (applicant) concluded three contracts with a Dutch buyer (respondent) for the supply of whey powder. The product met the requirements agreed upon according to the method of analysing prevalent in North America but failed to meet the requirements under the European method. As a result, the respondent cancelled the third contract which had not been executed and, when the claimant instituted the ICC arbitration proceedings (for damages arising out of the cancellation of the third contract), he counter-claimed for loss arising from the first two contracts that had been executed. The tribunal applied Swiss Law and ruled that all three contracts, "from an economic point of view... constitute one group". It however rejected the respondents counterclaim on merits because the first two contracts came after the discovery of the error.

The above case shows that an arbitral tribunal can entertain issues of counterclaim if it was not prohibited in the arbitration agreement. After entertaining the counterclaim, the tribunal will then take a decision which it deems necessary. That is, after listening to the arguments of the parties, on issues relating to the counterclaim, the tribunal will proceed to either reject or admit the counterclaim.

From the foregoing and as said earlier, counterclaim is not prohibited in arbitration. But contrary to litigation where the parties do not have the opportunity to prohibit the right to make a counterclaim when rightly presented, in arbitration, the parties are given the right to prohibit any possibility of counterclaim in the arbitration agreement.

Thus, where the parties intend to see their dispute resolved expeditiously (faster), they can stipulate a clause in the arbitration agreement prohibiting the right to a counterclaim. But where the parties are silent, the rights of the parties to make a counterclaim will be deduced from the intentions of the parties or the circumstances of the case (custom of the trade). However, it is recommended that, the OHADA legislator should expressly prohibit counterclaim in arbitration the same way in which it has expressly prohibited some recourses against the award. This will better guarantee the expediency of arbitration.

Another technique which has been used by the OHADA legislator to ensure speed in arbitration is that the OHADA legislator has excluded the possibility to make some types of recourses against the award. The OHADA legislator did not give the parties the opportunity to decide in the arbitration agreement on whether to prohibit these recourses or not. The legislator expressly prohibits these recourses in order to guarantee the expediency of arbitration.

\footnotetext{
${ }^{39}$ Award in case No. 377 of 13 August 1981. ICC Year book Vol. IX (1984), 124-130
} 


\section{The exclusion or prohibition of some types of recourses against the award}

In its desire to guarantee speed in dispute resolution by way of arbitration, the OHADA legislator prohibited the right to make some types of recourses against the award. The OHADA legislator prohibited the right to make an appeal (1), opposition (2) and a decision to set aside the judgement of a competent judge in the member state (3).The decision to set aside the judgement of a competent judge in a member state is accepted only when it is done in front of the CCJA.

\section{The prohibition of the right to make an ordinary appeal}

Prior to most arbitration hearing, the parties are required to agree that the decision of the impartial third-party arbitrator will be final- that is, binding and not appealable- no matter the result. ${ }^{40}$ This is to minimize the time for the finalisation of the dispute which is one of the reasons why parties choose to resolve their disputes by way of arbitration rather than through litigation where most often there is much delay in the finalisation of the dispute. Without such a finality clause, arbitration would turn into waste of everyone's time whenever one party did not like the result and decide to walk away from the decision of the arbitrator.

Under OHADA, even if the parties are silent on the prohibition of the right to make an appeal in the arbitration agreement, there is no right of ordinary appeal against the arbitral award. ${ }^{41}$

The OHADA legislator excluded the right of ordinary appeal against the arbitral award for practical reasons. This is to avoid time consumption. In effect to minimize the length of time for the finalisation of the dispute and hence guarantee the expediency required in arbitration ${ }^{42}$ in order to save cost and protect the objective of business, which is to maximise profit.

To exclude the right of ordinary appeal means that the principle of double degree of justice is not recognised in arbitration. Even if the parties stipulate in the arbitration agreement that each party can make an appeal against the decision of the arbitrator, the right shall not be recognised.43 In arbitration, the parties are expected to be judged in a single degree by an arbitrator and not in a double degree as is the case with litigation. The exclusion of the principle of double degree of justice in arbitration is a means to guarantee the expediency required in arbitration.

Appeal is not the only recourse against the award which has been prohibited by the OHADA legislator. In its desire to ensure the expediency required in arbitration, the OHADA legislator has also prohibited opposition.

${ }^{40}$ FREE ADVICE STAFF, Are There Appeals in Arbitration? Available at http://law.freeadice.com/litigation/appeals/arbitration appeals.htmixzz4HayesG2d. Last visited on the 26/7/2014.

${ }^{41}$ Article 25 of the OHADA U.A.A provided that: « the award is not subject to any... appeal...».

42 AFAPON JATSA (J-P.), L'efficacité de la sentence arbitrale dans l'acte uniform OHADA, Memoire de Maitrise, University of Dschang, 1999, p.28.

43 This provision is emphasized in Article 1487 of the N.C.P.C Française.

\section{The exclusion of opposition}

Opposition is a recourse in which a party who was not present at the hearing (defaulter) requests that the judgment against him be set-aside and the case reheard. In other words, it is a recourse which can be used by a person who was a victim of a judgement in default, demanding the court which rendered the judgment to set-aside the judgment and hear the case for the second time. This type of recourse which is permitted in litigation is not permitted in arbitration. Article 25 Paragraph 1 of the OHADA U.A.A stipulates that: «the award is not subject to any opposition,..».

In arbitration, opposition is excluded or prohibited to speed up the arbitration process. In litigation, opposition is permitted because the defendant might not have been informed that there is a case against him. The only remedy for him against the judgment passed in his absence would be opposition. This type of recourse is prohibited in arbitration because of the contractual nature of arbitration ${ }^{44}$. Since arbitration is considered to be contractual, the respondent cannot pretend that he was not aware of the arbitration. Any party who after concluding the arbitration agreement fails to participate in the arbitration is considered to have deliberately abandoned the arbitration proceedings.

A party may abandon a court proceeding deliberately in order to pretend that he was not aware of the proceedings. This is possible in litigation because the party who abandons the proceedings could subsequently resort to opposition when judgment has been delivered by the court. There is no doubt that this will obviously increase the length of time for the finalisation of the dispute. This is not possible in arbitration since a person cannot conclude an arbitration agreement and later say he was not aware of the agreement.

In addition to the above recourses which have been prohibited by the OHADA legislator against the award, the OHADA legislator has also excluded a judgement setting aside the decision of a competent judge in the member state

3. The exclusion of a judgement setting aside the decision of a competent judge in the member state

The arbitral award is insusceptible to a decision to set aside the judgement of a competent judge in the member state. To this effect, Article 25 Paragraph 1 of the OHADA U.A.A provides that: " the award is not subject to any... judgment setting it aside ».

However, the OHADA legislator permitted a decision setting aside the decision of a competent judge in a member state only when it is done in front of the CCJA. ${ }^{45}$

${ }^{44}$ LEBOULANGE (P.), «Presentation general des actes sur l'arbitrage », L'OHADA et Les Perspectives de l'arbitrage en Afrique, Travaux du centre René - Jean Dupuy pour le droit et le developpement, Bruylant Bruxelles, Volume 1, 2000, P. 63 .

45 TCHAKOU (J-M.), «Le système d'arbitrage de la Cour commune de justice et d'arbitrage en question», Revue Camerounaise de l'arbitrage, Numéro Spécial (2), Février 2010, p.173. 


\section{The acceptance of a decision setting aside the decision of a competent judge in the member state only when the application is directed to the CCJA}

Article 32 Paragraph 1 of the OHADA UAA stipulates that: « the ruling refusing the exequatur of the award can only be set aside by the Common Court of Justice and Arbitration» ${ }^{43}$. This provision is important because it accelerates the finalization of the dispute as compared to a situation where such problems were to be directed to the national courts. One of reasons why parties resort to arbitration is to avoid the delays which are faced in front of the national courts. ${ }^{44}$

\section{Conclusion}

Litigation is the pivot of distributing justice among the people. Litigation is the last resort for establishing rights of an aggrieved person. But litigation is not efficient enough in delivering justice because of delay. There are a number of elements which act as the root causes of delay in the final resolution of a dispute via litigation. These causes include : absence of a timeline for a dispute resolved through the use of litigation to be finalised, obligation of the court to recognise the right of a party to make a counter claim and the recognition of the right of a party in litigation to make an appeal. Arbitration has been able to avoid all these cases of delay witnessed in litigation. The OHADA legislator has therefore used a number of mechanisms to avoid delay in the finalisation of a dispute via arbitration. In doing so, the OHADA legislator has stated a timeline within which a dispute resolved by way of arbitration should be finalized, the legislator has prohibited the possibility to make some recourses against the arbitral award and under OHADA, it is possible for the parties to prohibit the right to make a counterclaim in the arbitration agreement. But nonetheless OHADA has not expressly prohibited counterclaim in arbitration the same way in which it has expressly prohibited some recourses against the award. Against this backdrop, it is recommended that, the OHADA legislator should expressly prohibit counterclaim in arbitration as it is the case with some recourses against the award which have been expressly prohibited by the OHADA legislator.

${ }^{43}$ See also Article 25 paragraph 4 of the same Uniform Act which stipulate that: «the decision of the competent judge in the member state can only be set aside by the Common Court of Justice and Arbitration».

${ }^{44}$ SOH FOGNO (D-R.), Le judge etatique en matiere arbitrale dans l'espace OHADA, Masters thesis,University of Dschang, July 2001, p. 20; MOHAMED EI MEHDI, L'intervention du judge dans la procedure arbitral, PhD thesis, Université de Bordeaux, p. 192 ; 